\title{
Building Sector: The Different Ways to Improve Their Energetic Efficiency
}

\author{
Clito Afonso and Ricardo Pereira
}

Department of Mechanical Engineering, Faculty of Engineering of Porto University, Porto 4200-465, Portugal

\begin{abstract}
The building sector has a significant weight in the global energy consumption in almost of the countries. So, there is a high potential for increasing its energy efficiency. With the enforcement of the energetic certification, it was tried to select different solutions that presents less energy consumption and waste, as well as an effective reduction of $\mathrm{CO}_{2}$ emissions. This work fits in this perspective, since the main goal is to evaluate the contribution of passive and active solutions that can be used in buildings for the improvement of its energetic efficiency, as well as to evaluate the contribution of renewable energy sources. Contribution of solar systems for hot water heating and electric energy production has been studied, as well as cogeneration, Combined Heat and Power (CHP). The case studied is a hotel. To improve the building performance, there were proposed several changes, with the goal of evaluating the contribution of the different solutions proposed. It was concluded that they contribute to a reduction of thermal needs of $25.2 \%$ and avoided emissions of $\mathrm{CO}_{2}$ is $30.4 \%$. The analysis of the implementation of trigeneration, Combined Heat, Cooling and Power (CHCP) turns it executable. The payback period is less than 8 years.
\end{abstract}

Key words: $\mathrm{CHP}, \mathrm{CHCP}$, energy analysis, avoided $\mathrm{CO}_{2}$ emissions, economic analysis.

\section{Introduction}

Hotels are buildings which have high energy demands and water consumption that decisively reflects in operating costs. In the tertiary sector, they have great potentials for improving energy efficiency.

Thus, it is essential to develop a sustainable strategy in the building sector to keep in account the environmental, social and economic impact of all and each one the parts that make up the building. In this sense, energy optimization and resources play a major role in driving the operation of buildings. These concerns must be present and reflect up from the design phase, that is, in the early stages of development of their project. The energy optimization is to select the solutions that promote the reduction of energy consumption, waste and a reduction of emissions of greenhouse gases $\left(\mathrm{CO}_{2}\right)$.

It should be noted that the energy optimization of a building does not pass only by mandatory large

Corresponding author: Clito Afonso, mechanical engineer, $\mathrm{Ph} . \mathrm{D}$., professor. main research field: applied thermodynamics. measures with high energy impacts and operating costs. Very often, the adoption of small actions only represents small impacts. However, the sums of all of them are of importance for the intended purpose-to reduce energy consumption and associated operating costs.

Despite the importance assumed by using renewable energies in the tertiary sector, cogeneration remains as the most effective technology on the conversion of primary energy (fossil or renewable sources) into electricity and heat $[1,2]$. The application of cogeneration technologies on the third sector gains notability facing the rise of fuel prices and the need to ensure adequacy and comfort of space [3-6].

The micro-power generation, as an activity for low tension electricity production with the possibility of energy delivery to the public grid, it was regulated by several Decree-Laws [7, 8]. The actual ordinancestipulates that the electricity produced is destined predominantly for their own consumption, and the surplus that can be delivered to third parties or to the public, with $150 \mathrm{KW}$ limit in the case of power 
delivery to be made public. For the production of electricity on a large scale, using photovoltaics systems, the remuneration given to national electric system network is regulated by Decree-Law No. 225/2007 of 31 May [9]. Thus, the use of photovoltaic panels is becoming increasingly common practice more visible in several countries. So along with energy efficiency measures, the increasing integration of renewable energy in buildings, fits to aims to reach the 2020 targets stipulated. The energy consumption of the building is directly related to passive and active the solutions that will be analyzed.

In this work, a hotel located in Portugal was studied. The dynamic codes TRACE.700.v.6.2.5 and-Solterm-Térmico Solar in English: Solar Thermal-were used respectively for the evaluation of energy needs in HVAC-Heating Ventilation and Air Conditioning-system and for sanitary hot water demand. It was verified that the higher consumptions were on the electric ones, specifically the one of lightning (32.4\%) and the equipment's (25.8\%), followed by the HVAC, ventilation (11.6\%) and cooling (10.8\%). To analyze the contribution of different solutions, in order to increase the energetic efficiency of the hotel, there were made several changes on the transient computer model. The analysis of the technical/economic viability of the implementation of a cogeneration/trigeneration becomes at two levels, where the technologies tested were analyzed to adapt them to the thermal needs of the building. Among several solutions, namely micro turbines and fuel cells, it was chosen a system based on an internal combustion engine running on natural gas, with the help of an absorption chiller to produce the cooling load. The payback period of this solution is less than 8 years.

Parameters to be evaluated

- Payback time: is the project's operating time necessary to obtain the sum of revenue and expenditure flows that equalize the value of the investment in Eq. (1):

$$
\text { Payback }=\frac{\text { Initial Investment }}{\text { Annual } \operatorname{Re} \text { venues }}
$$

Energy Efficiency Index (EEI) $\left(\mathrm{kgep} \cdot \mathrm{m}^{2-} \cdot \mathrm{year}^{-1}\right)$. According to Decree-Laws already specified, there are several formulas to evaluate the EEI (not shown here) and deals with specific consumption for heating, cooling and lighting, for each typology. This parameter is important in order to define in which energy classes the building belongs.

- EEE (Equivalent Electrical Efficiency). By the Decree Laws in force, this parameter is given by Eq. (2):

$$
E E E=\frac{E}{C-\frac{T}{0.9-0.2 \frac{C R}{C}}}
$$

Where,

E (KWh): electricity generated annually by the cogeneration system, excluding the consumption in internal auxiliary power generation systems;

$\mathrm{T}$ (KWh): useful thermal energy consumed annually from the thermal energy produced by cogeneration, excluding the consumption in the internal auxiliary power generation systems;

$\mathrm{C}(\mathrm{KWh})$ : the primary energy consumed annually in the cogeneration system, evaluated from the lower heating value of fuel and other resources used;

CR (KWh): equivalent energy of renewable resources or industrial waste, agricultural or urban consumed annually in cogeneration facility.

EEE can assume the following values, according to the same Decrees-Laws:

EEE $\geq 0.55$ for installations using natural gas as fuel, gas petroleum or liquid fuels with the exception of fuel;

EEE $\geq 0.50$ for installations using fuel oil as fuel, alone or together with waste fuels;

EEE $\geq 0.45$ for installations using biomass as fuel or residual fuels, alone or in conjunction with a fuel support a percentage not exceeds $20 \%$ annual average.

For the case study, it will not be analysed the 
contribution of renewable resources. Thus the formula for calculating the EEE is reduced to the Eq. (3):

$$
E E E=\frac{E}{C-\frac{T}{0.9}} \geq 0.55
$$

For the CHP and CHCP the following parameter must also be evaluated.

- Electrical efficiency, $\eta_{\text {electrical }}$ :

$$
\boldsymbol{\eta}_{\text {electrical }}=E_{\text {grosselctricity }} / \text { Total fuel consumed; }
$$

- Thermal efficiency, $\eta_{\text {thermal }}$ :

$$
\boldsymbol{\eta}_{\text {thermal }}=E_{\text {gross thermal }} / \text { Total fuel consumed. }
$$

- $\mathrm{E}_{\mathrm{er}}$ : maximum quantity of electricity to provide annually to the Electric System of Public Service not higher than the value given by Eq. (4):

$$
E_{e r}=\left(4.5 \frac{E+T}{E+0.5 T}-4.5\right) E
$$

(4) Saving Energy Index (SEI): ratio of the fuel economy obtained in the cogeneration engine when compared to the amount of fuel consumed in a conventional installation, i.e. an electrical plant with an efficiency $\boldsymbol{\eta}_{\mathrm{c}}$, a boilerwith an efficiency $\boldsymbol{\eta}_{\mathrm{b}}$ and an electric chiller with a $\mathrm{COP}_{\text {comp. }}$. It is given by Eq. (5):

$$
E_{e r}=\left(4.5 \frac{E+T}{E+0.5 T}-4.5\right) E
$$

(5) Where, RCE and RFE are respectively the ratios between heat and electricity and the ratio between cooling and electricity in the CHCP.

\section{Annual Thermal Analisys of the Hotel}

In the base case, it was followed the RCCTE (Council Regulation of the Characteristics of the Thermal Behavior of Buildings). The $\mathrm{U}$ values of the internal and external envelope were calculated and are displayed in Table 1.

As already mentioned, the energy needs of the hotel were simulated with the dynamics codes TRACE700 v. 6.2.5 and SOLTERM-Solar Thermal-the results being displayed in Table 2. It is also shown the values of EEI as well as the emitted $\mathrm{CO}_{2}$ associated with the energy consumption.

It must be noticed that the electric heating corresponds to the consumption of operation of heating systems, including pumps condensate, burner and control panel of the boilers. The gas heating corresponds to the consumption of boilers, with an efficiency of $83.3 \%$, and cooling corresponds to the electrical consumption of chillers with a Coefficient of Performance (COP) equal to 3.2. The ventilation represents the consumption of the air handling equipment, while the pumps correspond to the consumption associated with all fluid pumping equipment.

The maximum thermal power loads for heating and cooling are respectively equal 1,775.8 $\mathrm{KW}$ and 1,920.1 KW. The values given above were obtained with a reference system composed of an electric air-to-air chiller (COP of 3.2) and a conventional boiler with an efficiency of $83.3 \%$. It should be noted that the electric heating, represents the consumption of operation of heating systems, including pumps condensate, the burner and control panel of the boilers. The gas heating represents consumption of boilers and the cooling corresponds to the electrical consumption of chillers.

It is important to highlight the "parameters" which most contribute to the nominal consumption of primary energy are the lighting consumption and electrical equipment. Also, it is noted that the building presents elevated energy consumption, due to the fact it is a large service building. However, even in the base case on predefined conditions, the building is already within the minimum required by Regulation

Table $1 \mathrm{U}$ values $\left[\mathrm{W} \cdot \mathrm{m}^{2-.0} \mathrm{C}^{-1}\right]$ for the base case.

\begin{tabular}{lll}
\hline & & $\mathrm{U}$ values $\left(\mathrm{W} \cdot \mathrm{m}^{\left.2-\cdot{ }^{-0} \mathrm{C}^{-1}\right)}\right.$ \\
\hline \multirow{2}{*}{ External envelope } & Walls & 1.80 \\
& roof and floor & 1.25 \\
\hline \multirow{2}{*}{ Internal envelope } & Walls & 2.00 \\
& roof and floor & 1.65 \\
\hline
\end{tabular}


Table 2 Annual thermal needs of the hotel (base case).

\begin{tabular}{|c|c|c|c|c|c|c|}
\hline & & & $\begin{array}{l}\text { Useful thermal needs } \\
{\left[\mathrm{KWh}^{\prime} \text { year }^{-1}\right]}\end{array}$ & $\begin{array}{l}\text { Nominal primary } \\
\text { thermal energy } \\
{\left[\mathrm{kgep}^{-} \text {year }^{-1}\right]}\end{array}$ & EEI $\left[\mathrm{kgep} \cdot \mathrm{m}^{2-} \cdot\right.$ year $\left.^{-1}\right]$ & $\begin{array}{l}\mathrm{CO}_{2} \text { emissions } \\
\left.\text { [tons } \mathrm{CO}_{2}\right]\end{array}$ \\
\hline \multirow{3}{*}{$\mathrm{H} \& \mathrm{C}$} & \multirow{2}{*}{ Heating } & Electric & 19,724 & 5,720 & 0.27 & 6.9 \\
\hline & & Gas & 24,6731 & 21,219 & 1.0 & 25.3 \\
\hline & \multicolumn{2}{|l|}{ Cooling } & 521,389 & 151,203 & 5.19 & 181.4 \\
\hline \multirow{12}{*}{ Others } & \multicolumn{2}{|l|}{ Lighting } & $1,141,168$ & 330,939 & 15.61 & 397.1 \\
\hline & \multicolumn{2}{|c|}{ Electric equipment } & 909,071 & 263,631 & 12.43 & 316.4 \\
\hline & \multicolumn{2}{|c|}{ Gas equipment } & 439,081 & 37,761 & 1.78 & 45.3 \\
\hline & \multicolumn{2}{|c|}{ Ventilation } & 498,000 & 144,420 & 5.56 & 173.73 \\
\hline & \multicolumn{2}{|c|}{ Pumps } & 238,800 & 69,252 & 2.67 & 83.1 \\
\hline & \multicolumn{2}{|c|}{ Hydraulic equipment } & 4,729 & 1,371 & 0.06 & 1.6 \\
\hline & \multirow{2}{*}{ SHW } & Gas & 636,318 & 54,723 & 2.58 & 65.7 \\
\hline & & Electric & 10,143 & 2,941 & 0.14 & 3.5 \\
\hline & \multirow{2}{*}{ SPH } & Electric & 4,840 & 1,404 & 0.07 & 1.7 \\
\hline & & Gas & 161,678 & 13,904 & 0.66 & 16.7 \\
\hline & \multicolumn{2}{|c|}{ Mechanical equipment } & 6,572 & 1,906 & 0.09 & 2.3 \\
\hline & \multicolumn{2}{|l|}{ Total } & $4.84\left[\mathrm{GWh} \cdot \mathrm{year}^{-1}\right]$ & $\begin{array}{l}1,100 \\
{\left[\text { tep }^{\text {year }}{ }^{-1}\right]}\end{array}$ & 48.1 & $1,320.5$ \\
\hline
\end{tabular}

Table 3 The annual energy billing and associated costs.

\begin{tabular}{lll}
\hline & Total thermal load [MWh/year] & Fuel Bill [€/year] \\
\hline Electricity & $3,354.43$ & 275,890 \\
Gas & $1,483.81$ & 46,148 \\
Total & 4,838 & 322,038 \\
\hline
\end{tabular}

Characteristics of the Thermal Performance of Buildings [10]. The annual energy bill and associated costs are shown in Table 3.

Due to the legislation in force, the hotel features an energy rating of $\mathrm{B}^{-}$(EEI nominal $=48.10$ less than EEI reference value $=49.02 \mathrm{kgep} \cdot \mathrm{m}^{2-} \cdot$ year $\left.^{-1}\right)$. So it's mandatory to improve the building components in order to reach a higher rating class. This goes through in adoption of passive and active solutions.

\section{Improved Passive Solutions}

\subsection{Opaque Envelope}

The interior space of the building is physically separated from the outside by an envelope that is composed of opaque (walls, roof and floor) and a transparent part (glazing). Note that for this first analysis, to the glazed envelope have been given the maximum permissible values of solar factor and heat transfer, set out in Regulamento das Características de Comportamento Térmico dos Edifícios (RCCTE). In English: Regulation Characteristics of the Thermal Performance of Buildings [11]. In order to improve the efficiency of the building, regarding the opaque envelope, four alternatives were proposed. These ones are only due to changes of the $U$ values of the internal and external opaque envelope due to the changes in thermal insulation. The alternatives are always according to RCCTE:

Alternative 1 (ALT 1): the $U$ values are the reference ones;

Alternative 2 (ALT 2): $25 \%$ improvement on the reference values;

Alternative 3 (ALT 3): 50\% improvement on the reference values;

Alternative 4 (ALT 4): $75 \%$ improvement on the reference values.

The alternatives are shown in Table 4. 
Table $4 \mathrm{U}$ values $\left[\mathrm{Wm}^{2-\cdot .{ }^{0}} \mathrm{C}^{-1}\right]$ for the base case and for four different alternatives.

\begin{tabular}{lllllll}
\hline & & Base case & Alt 1 & Alt 2 & Alt 3 & Alt 4 \\
\hline External & Walls & 1.8 & $0.7(61 \%)$ & $0.525(25 \%)$ & $0.35(33 \%)$ & $0.175(50 \%)$ \\
envelope & Roof and floor & 1.25 & $0.5(60 \%)$ & $0.375(25 \%)$ & $0.25(33 \%)$ & $0.125(50 \%)$ \\
Internal & Walls & 2 & $1.4(30 \%)$ & $1.05(25 \%)$ & $0.7(33 \%)$ & $0.35(50 \%)$ \\
envelope & Roof and floor & 1.65 & $1(39 \%)$ & $0.75(25 \%)$ & $0.5(33 \%)$ & $0.25(50 \%)$ \\
\hline
\end{tabular}

Table 5 Annual thermal needs of the hotel: base case simulation and alternatives for the opaque envelope.

\begin{tabular}{|c|c|c|c|c|c|c|}
\hline & Base case & Alt 1 & Alt 2 & Alt 3 & Alt 4 & \\
\hline \multirow{2}{*}{ Heating } & 0.27 & 0.25 & 0.24 & 0.22 & 0.22 & \multirow{6}{*}{$\begin{array}{l}\text { Kgep } \cdot m^{2-} \\
\text { 'year }\end{array}$} \\
\hline & 1 & 0.36 & 0.27 & 0.2 & 0.15 & \\
\hline Cooling & 5.19 & 4.59 & 4.53 & 4.48 & 4.45 & \\
\hline Ventilation & 5.56 & 4.99 & 4.97 & 4.87 & 4.91 & \\
\hline Pumps & 2.67 & 1.41 & 1.38 & 1.37 & 1.37 & \\
\hline $\mathrm{EEI}_{\text {nominal }}$ & 48.1 & 44.99 & 44.77 & 44.53 & 44.49 & \\
\hline Consumption & $1,100.4$ & $1,029.5$ & 1,026 & $1,021.6$ & 1022 & tep·year ${ }^{-1}$ \\
\hline Total Energy & 228 & 211 & 210 & 209 & 208 & $\mathrm{KWh} \cdot \mathrm{m}^{2-} \cdot$ year $^{-1}$ \\
\hline $\mathrm{CO}_{2}$ emissions & $1,320.5$ & $1,235.4$ & $1,231.2$ & $1,225.9$ & $1,223.4$ & tons $\mathrm{CO}_{2}$ equiv $\cdot$ year $^{-1}$ \\
\hline Costs & - & 104.5 & 189.4 & 316.4 & 845.5 & {$\left[€ \cdot 10^{3}\right]$} \\
\hline Payback time & - & 5.6 & 9.6 & 15.1 & 40.4 & Years \\
\hline
\end{tabular}

The values in parenthesis correspond to the reduction of heat transfer coefficients between the alternatives. From this analysis it is emphasized that the greatest reduction occurs between the base case and alternative one.

The optimization process of the opaque envelope goes through the analysis of its contribution to the energy consumption of the building. Table 5 shows the annual energy consumption of the hotel regarding the alternatives for the opaque envelope as well as the values of EEI and the emitted $\mathrm{CO}_{2}$ associated with the energy consumption. There are also shown the total costs and the payback time of all alternatives.

The baseline for this analysis is the opaque envelope, the base case from which follows that it is not relevant to improve the $U$ value of the opaque envelope beyond the reference values stipulated by RCCTE, since the decrease of the $U$ values of the opaque envelope, beyond the benchmarks, do not translates into a significant improvement of the final value of the primary energy consumption (Table 5, consumption: between Alt 1 and Alt 4 the difference is $0.73 \%$ ). As can also be observed in the same table, it is apparent that the transition of the $U$ values of the opaque envelopewhen compared with the alternative one (ALT 1), presents a decrease in the consumption, both for heating $(4.27 \%)$ and cooling (14.3\%) and consequent reduction of ventilation and pumping systems. As can be seen, alternative 1 is the best one when compared to the base case, even due to the payback time. Besides these benefits there is no improvement in the energetic classification of the hotel (to reach class $B$ the EEI should be less than $44.1 \mathrm{Kgep} \cdot \mathrm{m}^{2-} \cdot$ year$)$.

\subsection{Glazing Envelope}

As the best solution for the opaque envelope is alternative 1, the values were fixed in order to evaluate the alternatives for different types of glazing and frames. With the code Calumen of Saint-Gobain there were analyzed four different alternatives of double glazing regarding the Solar Factor (SF):

Alternative 1 (ALT 1): $\mathrm{SF}=0.45$;

Alternative 1 (ALT 2): $\mathrm{SF}=0.4$;

Alternative 1 (ALT 3): $\mathrm{SF}=0.35$;

Alternative 1 (ALT 4): $\mathrm{SF}=0.3$.

For each alternative, there were analyzed different frames being them metallic with or without thermal 
cut or of wood or plastic. The energetic and economic analyses are displayed respectively in Table 6 and Table 7 .

From the results of the analysis, it is concluded that a window with a low solar factor there is a reduction in thermal cooling requirements. However, it causes increased heating requirements, leading the need to find an optimal point associated with the improvement of the glazed envelope. It was chosen a glass with a solar factor 0.40 , since this solution becomes attractive in terms of payback time.

\section{Active Solutions}

3.1 Solar Thermal Panels for Sanitary hot Water and Swimming pool and PV's for Electricity Production

Decree-Law No. 79/2006 turns out the compulsory installation of solar panels for hot water in new buildings or major rehabilitation of buildings. In this

Table 6 Cost savings using glazed envelope with different frames.

\begin{tabular}{|c|c|c|c|c|c|c|}
\hline \multicolumn{2}{|c|}{ Double glazing } & \multirow{2}{*}{ Type of consumption } & \multirow{2}{*}{$\begin{array}{l}\text { Annual energetic } \\
\text { consumption } \\
{\left[\mathrm{MWh}^{-} \text {year }^{-1}\right]}\end{array}$} & \multirow{2}{*}{$\begin{array}{l}\text { Annual energetic } \\
\text { costs } \\
{\left[€ \cdot 10^{3} \cdot \text { year }^{-1}\right]}\end{array}$} & \multirow{2}{*}{$\begin{array}{l}\text { Total } \\
{\left[€ \cdot 10^{3} \cdot \text { year }^{-1}\right]}\end{array}$} & \multirow{2}{*}{$\begin{array}{l}\text { Cost savings } \\
{\left[€ \cdot 10^{3} \cdot \text { year }^{-1}\right]}\end{array}$} \\
\hline Frame & SF & & & & & \\
\hline \multirow{2}{*}{\multicolumn{2}{|c|}{ Base case $(0.56)$}} & Electricity & 3,157 & 262 & \multirow{2}{*}{303.4} & \multirow{2}{*}{-} \\
\hline & & Gas & 1,327 & 41.6 & & \\
\hline \multirow{8}{*}{$\begin{array}{l}\text { Metal without } \\
\text { thermal cutting }\end{array}$} & \multirow{2}{*}{0.45} & Electricity & 3,105 & 258 & \multirow{2}{*}{300} & \multirow{2}{*}{3.6} \\
\hline & & Gas & 1,329 & 42 & & \\
\hline & \multirow{2}{*}{0.4} & Electricity & 3,068 & 255 & \multirow{2}{*}{297} & \multirow{2}{*}{6.2} \\
\hline & & Gas & 1,332 & 42 & & \\
\hline & \multirow{2}{*}{0.35} & Electricity & 3,036 & 253 & \multirow{2}{*}{295} & \multirow{2}{*}{8.3} \\
\hline & & Gas & 1,336 & 42 & & \\
\hline & \multirow{2}{*}{0.3} & Electricity & 3,005 & 251 & \multirow{2}{*}{293} & \multirow{2}{*}{10.4} \\
\hline & & Gas & 1,338 & 42 & & \\
\hline \multirow{8}{*}{$\begin{array}{l}\text { Metal with } \\
\text { thermal cutting }\end{array}$} & \multirow{2}{*}{0.45} & Electricity & 3,118 & 259 & \multirow{2}{*}{300} & \multirow{2}{*}{2.9} \\
\hline & & Gas & 1,321 & 41 & & \\
\hline & \multirow{2}{*}{0.4} & Electricity & 3,084 & 257 & \multirow{2}{*}{298} & 52 \\
\hline & & Gas & 1,322 & 41 & & 5.2 \\
\hline & 025 & Electricity & 3,118 & 259 & 300 & 76 \\
\hline & 0.35 & Gas & 1,323 & 41 & 300 & 1.0 \\
\hline & 03 & Electricity & 3,020 & 252 & 294 & 07 \\
\hline & 0.3 & Gas & 1,325 & 42 & 294 & 9.7 \\
\hline & 0.15 & Electricity & 3,131 & 260 & 201 & 2 \\
\hline & 0.45 & Gas & 1,318 & 41 & 301 & 2 \\
\hline & 04 & Electricity & 3,097 & 258 & 299 & 45 \\
\hline Wood & & Gas & 1,318 & 41 & & \\
\hline Wood & 25 & Electricity & 3,064 & 255 & 207 & 60 \\
\hline & 0.35 & Gas & 1,318 & 42 & 291 & 0.8 \\
\hline & 03 & Electricity & 3,031 & 253 & 294 & 91 \\
\hline & & Gas & 1,319 & 41 & & \\
\hline & 0.15 & Electricity & 3,139 & 261 & 302 & 15 \\
\hline & 0.45 & Gas & 1,317 & 41 & 302 & 1.5 \\
\hline & 0.4 & Electricity & 3,100 & 258 & 290 & 43 \\
\hline Plastic & & Gas & 1,317 & 41 & & \\
\hline Flastic & 035 & Electricity & 3,066 & 255 & 207 & 67 \\
\hline & 0.35 & Gas & 1,317 & 42 & 291 & 6.1 \\
\hline & 03 & Electricity & 3,033 & 253 & 294 & 9 \\
\hline & 0.3 & Gas & 1,318 & 41 & 294 & 9 \\
\hline
\end{tabular}


Table 7 Payback time of different kinds of windows.

\begin{tabular}{llll}
\hline & $\begin{array}{l}\text { Total costs } \\
{\left[€ \cdot 10^{3}\right]}\end{array}$ & Increase in investment $\left[€ \cdot 10^{3}\right]$ & Payback time [years] \\
\hline SF & & & \\
Base case $(0.56)$ & 332 & - & - \\
0.45 & 362 & 30.2 & $8.4-19.7$ \\
0.4 & 377 & 45.3 & $7.3-10.6$ \\
0.35 & 407 & 75.4 & $9.1-11.3$ \\
0.3 & 422 & 91 & $8.7-10.0$ \\
\hline
\end{tabular}

Table 8 Comparison between solar thermal panels: amorphous silicon and polycrystalline silicon.

\begin{tabular}{|c|c|c|c|c|c|c|c|}
\hline \multicolumn{8}{|l|}{ Amorphous silicon panels } \\
\hline Power peak $\left[\mathrm{KW}_{\mathrm{p}}\right]$ & - & 3.68 & 10 & 20 & 30 & 100 & 150 \\
\hline Solar capture area $\left[\mathrm{m}^{2}\right]$ & - & 62.92 & 171.6 & 343.2 & 500.5 & 1,716 & $2,516.8$ \\
\hline $\mathrm{N}^{\mathrm{o}}$ of modules & - & 44 & 120 & 240 & 350 & 1,200 & 1,760 \\
\hline Produced energy [MWh·year $\left.{ }^{-1}\right]$ & - & 6.6 & 18.3 & 36 & 53 & 186 & 268 \\
\hline $\mathrm{EEI}_{\text {nominal }}\left[\mathrm{Kgep} \cdot \mathrm{m}^{2-\cdot}\right.$ year $\left.^{-1}\right]$ & 44.25 & 44.16 & 44 & 43.8 & 45.6 & 42 & 41 \\
\hline \multicolumn{8}{|l|}{ Polycrystalline silicon panels } \\
\hline Power peak $\left[\mathrm{KW}_{\mathrm{p}}\right]$ & - & 3.68 & 10 & 20 & 30 & 100 & 150 \\
\hline Solar capture area $\left[\mathrm{m}^{2}\right]$ & - & 28.9 & 76.9 & 147 & 368 & 736 & 1,088 \\
\hline $\mathrm{N}^{\mathrm{o}}$ of modules & - & 18 & 48 & 92 & 230 & 460 & 680 \\
\hline Produced energy [MWh'year $\left.{ }^{-1}\right]$ & - & 6.9 & 19 & 35 & 89 & 182 & 270 \\
\hline $\mathrm{EEI}_{\text {nominal[ }}\left[\mathrm{Kgep}_{\mathrm{m}^{2-}} \cdot \mathrm{year}^{-1}\right]$ & 44.25 & 44.16 & 44 & 43.8 & 41 & 42 & 41 \\
\hline
\end{tabular}

hotel they will be used for sanitary hot water and swimming pool. The main characteristics of the solar thermal panels are: optical yield of 0.74 , a solar capture area of $2 \mathrm{~m}^{2}$ and a thermal loss coefficient $\mathrm{a}_{1}=$ $3.9 \mathrm{~W} / \mathrm{m}^{2} / \mathrm{K}$ and $\mathrm{k}_{2}=0.013 \mathrm{~W} / \mathrm{m}^{2} / \mathrm{k}^{2}$.

An economic study was also done, similar to the previous cases. For the building under consideration, if using a solar capture area higher to $200 \mathrm{~m}^{2}$, the system is no longer economically viable because the payback time is greater than the lifetime of the equipment. It should be noted that the selection criteria of this type of equipment cannot be only based on an economic assessment. It should also be taken into account the energy contribution that this type of equipment has to each situation under review. The lower payback time is around 8 years which corresponds to an area of $25 \mathrm{~m}^{2}$. For this situation, the EEI is $41.5 \mathrm{Kgep} \cdot \mathrm{m}^{2-}$.year ${ }^{-1}$ and becomes less than the reference value, $44.1 \mathrm{Kgep} \cdot \mathrm{m}^{2-} \cdot \mathrm{year}^{-1}$. So the hotel can be included in class $B$.

The PV panels, in despite of the high initial investment, is ecologically clean, with long life and do not require great care in terms of maintenance. For the contribution of this technology in the building, the analysis was done according to the maximum power peak of the photovoltaic system to be used, where it was tested the contribution of three different types of panels, such as amorphous silicon ones, the polycrystalline silicon and their integration in the facades (BiPV). The results of the comparison between them are shown in Table 8 . The BiPV was discard from the analysis because the modules are arranged vertically which harms much the production of these panels.

From the results obtained for the two types of photovoltaic panels, it was concluded that for the same peak power, the annual energy produced by amorphous silicon panels and the poly-crystalline silicon is quite similar between them, which is reflected in a decrease the overall consumption of the building in a very similar manner. Although these two different types of panelshas for the same peak power a very similar annual energy production, the amorphous silicon panels arepenalizedbecause they 
require more than twice the solar capture area. So it was chosen for the following analysesthe polycrystalline silicon panels-92 modules with a power pick of $20 \mathrm{KW}_{\mathrm{p}}$. The EEI is $42 \mathrm{Kgep} \cdot \mathrm{m}^{2-} \cdot$ year $^{-1}$ which maintains the hotel in class $\mathrm{B}$, beside the benefits were shown in Table 8 .

\subsection{Others Improvements}

Several other improvements were taken into account. In order to not repeat the same kind of tables, only the final results of each one will be shown in this subsection. Ventilation devices

In order to improve the efficiency of ventilation equipment, consideration will be given to influence of HVAC systems with and without heat recovery, as well as the influence of consumption of the equipment associated with them. Between several options, the final one was that the air velocity in the batteries (heating and cooling), did not exceed $2.5 \mathrm{~m} \cdot \mathrm{s}^{-1}$ whit the respective reduction of the total pressure drop in ducts and with heat recovery. Comparing with the base case, the percentage of the total energy saved is $2.9 \%$, and the avoided $\mathrm{CO}_{2}$ emissions represent $4.1 \%$. The EEI value is $42.79 \mathrm{Kgep} \cdot \mathrm{m}^{2-} \cdot$ year, less than the reference value.

Lighting control equipment-dimmers. The control of artificial lighting in a building aims to maximize the use of natural lighting, requiring only lighting and occupancy sensors in the spaces. These detect the presence of space lighting power, comparing it with the preset. If it is not achieved by natural lighting is driven artificial lighting. The TRACE.700.v.6.2.5 software has an algorithm that allows the inclusion of the concept of natural light into the building, creating in each space a variable named daylight factor, defined by the ratio between indoor luminance and the horizontal exterior luminance. The implementation of such control system reverts in a reduction of the annual energy bill of around $7 \%$. The contribution to this decrease comes from the electricity consumption that is reduced considerably due to lower power consumption in the building using this technology. The payback time is 1.3 years.

Chillers using heat recovery of hot water from the condensers to heat the sanitary hot water (SHW). After an energetic and economic analysis, it was found out that using this technique, there is an expected increase in power consumption by the latter, by the reason ofits contribution to the SHW (there is a significant reduction in nominal power to SHW). The greatest contribution of this equipment to satisfy the SWH takes place in the cooling season (summer), since in this period the chillers are running permanently (feeding the cooling batteries).

They take advantage of the flue gas which from the combustion Condensing boilers. The use of condensing gas boilers leads to a decrease in overall building consumption due to their better performance when compared to conventional boilers.

\subsection{Overall Solutions}

Taking into account the better solutions for each active solution shown before, it's possible to compare them with the initial conditions. Table 9 displays the overall results of the best choices in order to reduce the energy consumption of the building.

As can be seen, with the features inherent in the initial solution (base case) when compared to the optimal solution set, the differences in all consumption levels decrease in a meaningful way. The reduced overall consumption of the building is approximately $25 \%$. For the base case an according to the Portuguese legislation, theenergy rating of the hotel was $\mathrm{B}^{-}$category. Therefore, after the changes carried out the building was rated to class $\mathrm{A}$.

\subsection{Cogeneration (CHP) and Trigeneration (CHCP)}

Depending on the electrical power of the engineto be used and of the annual operating hours of the system, it's possible to evaluate the electricity produced annually by the equipment. In turn, the useful thermal energy depends on the thermal requirements of the 
Table 9 Results of the final solution.

\begin{tabular}{|c|c|c|c|c|c|c|c|}
\hline & & \multicolumn{2}{|c|}{ Final solution } & \multicolumn{2}{|c|}{ Initial solution } & \multirow{2}{*}{$\begin{array}{l}\text { Reduction of } \\
\text { energy } \\
\text { consumption }\end{array}$} & \multirow{2}{*}{$\begin{array}{l}\text { Avoided emissions } \\
\text { of } \mathrm{CO}_{2} \\
\%[-]\end{array}$} \\
\hline & & $\begin{array}{l}\text { kgep } \cdot \mathrm{m}^{2-} \\
\left.\text { year }^{-1}\right]\end{array}$ & tons $\mathrm{CO}_{2}$ & $\begin{array}{l}{\left[\mathrm{kgep} \cdot \mathrm{m}^{2-}\right.} \\
\left.\text { year }^{-1}\right]\end{array}$ & tons $\mathrm{CO}_{2}$ & & \\
\hline \multirow{2}{*}{ Heating } & Electric & 0.27 & 6.8 & 0.27 & 6.9 & 1.6 & \\
\hline & Gas & 0.36 & 9.1 & 1.0 & 25.3 & 64.2 & \\
\hline \multicolumn{2}{|c|}{ Electric cooling } & 4.49 & 157 & 5.19 & 181.4 & 13.5 & \\
\hline \multicolumn{2}{|c|}{ Lighting } & 12.95 & 329 & 15.61 & 397.1 & 17.1 & \\
\hline \multicolumn{2}{|c|}{ Electric equipment } & 12.43 & 316.4 & 12.43 & 316.4 & - & \\
\hline \multicolumn{2}{|c|}{ Gas equipment } & 1.78 & 45.3 & 1.78 & 45.3 & - & \\
\hline \multicolumn{2}{|c|}{ Ventilation } & 2.62 & 85.8 & 5.56 & 173.73 & 52.9 & \\
\hline \multicolumn{2}{|l|}{ Pumps } & 0.52 & 16.9 & 2.67 & 83.1 & 80.7 & \\
\hline \multicolumn{2}{|c|}{ Hydraulic equipment } & 0.03 & 0.08 & 0.06 & 1.6 & 46.5 & \\
\hline \multirow{2}{*}{ SWH } & Electric & 0.54 & 13.7 & 2.58 & 65.7 & 79.1 & \\
\hline & Gas & 0.14 & 2941 & 0.14 & 3.5 & 0.9 & \\
\hline \multirow{2}{*}{ SPH } & Electric & 0.07 & 1.7 & 0.07 & 1.7 & 5.4 & \\
\hline & Gas & 0.52 & 13.1 & 0.66 & 16.7 & 21.9 & \\
\hline \multicolumn{2}{|c|}{ Mechanical equipment } & 0.09 & 2.3 & 0.09 & 2.3 & 0.1 & \\
\hline \multicolumn{2}{|c|}{ Solar thermal } & -0.32 & -8.1 & - & - & - & \\
\hline \multicolumn{2}{|c|}{ PV } & -0.48 & -12.1 & - & - & - & \\
\hline \multicolumn{2}{|l|}{ Total } & 36 & 918.8 & 48.1 & 1320.5 & 25.2 & 30.4 \\
\hline
\end{tabular}

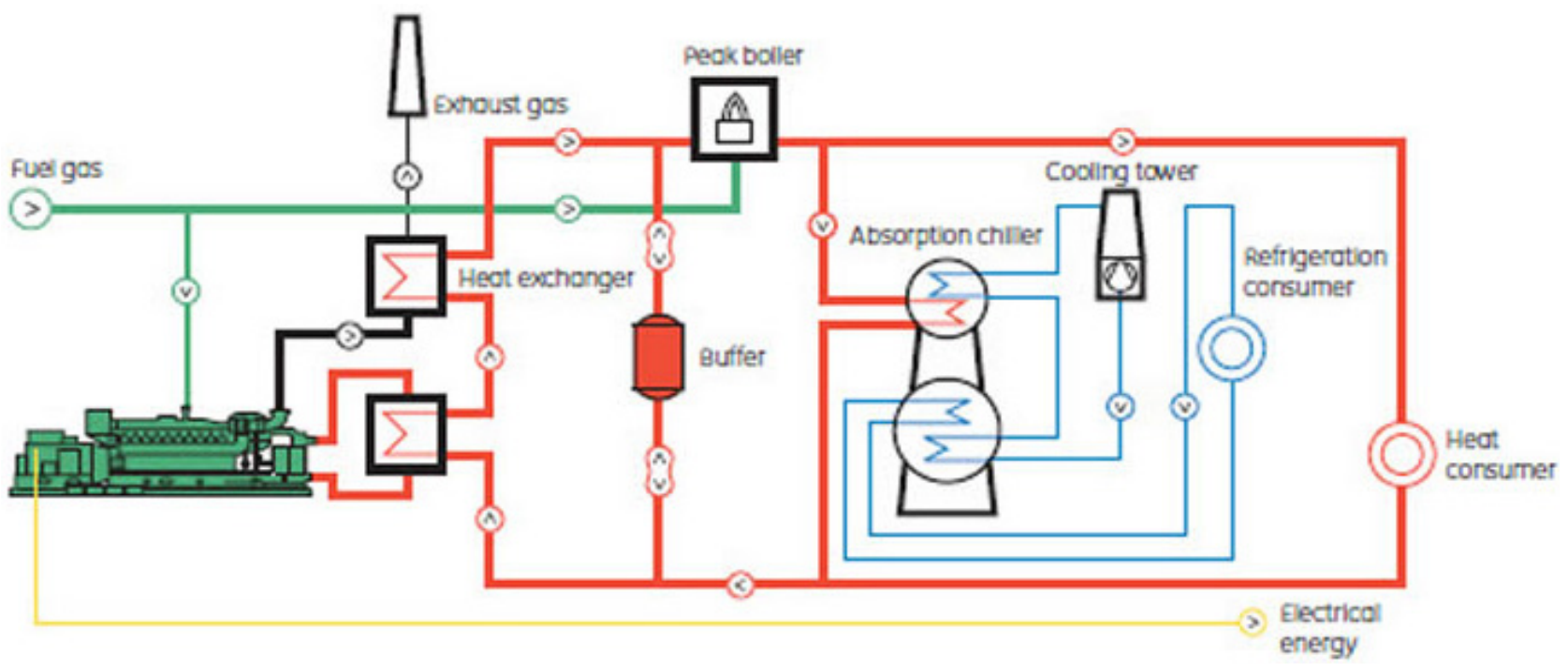

Fig. 1 General principle of a CHCP system.

building, because such a system only produces heat (besides the electricity). To be able to produce coolingit is necessary to have an absorption chiller that runs with the heat generate by the CHP. In this case such systems are designated as trigeneration systems - Combined Production of Heat, Cooling and Power (CHCP). In the case study, due to the involved thermal needs, is interesting to couple an absorption chiller for the cooling needs. A general sketch of a CHCP is shown in Fig. 1.

There were analyzed several types of cogenerations systems, namely four strokes engines running with natural gas, micro turbines and fuel cells. Among them, the one that better fits to the thermal needs of hotel is a specific one with the following characteristic as shown in Table 10. 
Table 10 Characteristics of the CHP engine.

\begin{tabular}{llllll}
\hline $\begin{array}{l}\text { Electric power } \\
{[\mathrm{KW}]}\end{array}$ & $\begin{array}{l}\text { Thermal power } \\
{[\mathrm{KW}]}\end{array}$ & $\begin{array}{l}\text { Gas consumption } \\
{[\mathrm{KW}]}\end{array}$ & $\begin{array}{l}\text { Electric } \\
\text { efficiency[\%] }\end{array}$ & $\begin{array}{l}\text { Thermal } \\
\text { efficiency[\%] }\end{array}$ & $\begin{array}{l}\text { Global efficiency } \\
{[\%]}\end{array}$ \\
\hline 330 & 363 & 851 & 38.78 & 42.66 & 81.43 \\
\hline
\end{tabular}

Table 11 Contribution of the CHCP for the energetic needs as a function of the running hours per year.

\begin{tabular}{llccccc}
\hline Thermal needs & CHCP & $\begin{array}{c}\text { Conventional } \\
\text { system }\end{array}$ & CHCP & $\begin{array}{c}\text { Conventional } \\
\text { system }\end{array}$ & CHCP & $\begin{array}{c}\text { Conventional } \\
\text { system }\end{array}$ \\
\hline & $\%$ & & $\%$ & & $\%$ & \\
\hline Heating & 94.28 & 5.72 & 70.97 & 29.03 & 41.75 & 58.25 \\
Cooling & 39.32 & 60.68 & 39.22 & 60.78 & 41.12 & 58.88 \\
Annual operating hours & & $8,760 \mathrm{~h} \cdot \mathrm{year}^{-1}$ & & $6,205 \mathrm{~h} \cdot \mathrm{year}^{-1}$ & & $4,380 \mathrm{~h} \cdot \mathrm{year}^{-1}$ \\
\hline
\end{tabular}

It should be noted that the operating system defined for the system CHCP is that the heat produced by the system first meets the heating needs, and only suppliesheat to the absorption chillers to satisfy the cooling demandswith the surplus heat not used in heating.

In order to verify the feasibility of this type of system, it is necessary to define its annual operating hours, which for the case study will be analyzed three different possibilities. It runs 24 hours a day $(8,760$ $\mathrm{h} /$ year), or from $7 \mathrm{am}$ to 24 hours $(6,205 \mathrm{~h} /$ year $)$ because this schedule eliminates much of the super-peak and standard empty electricity (uninteresting of the remuneration level), or from 10 am to $21 \mathrm{~h}(4,380$ $\mathrm{h} /$ year). Table 11 shows the contribution of the CHCP when compared to the base case.

For the chosen engine, the EEE value is checked (EEE $\geq 0.55$ ) using just one or two engines. It is also be concluded that the use of this engine and its hours operation, there is the economic viability of this technology as well as the obligation to use it (payback time $<8$ years.)

\section{Conclusions}

In this work, it was carried out an energetic and economic analysis of the contribution of passive and active solutions for buildings in order to reduceits energy consumptionas well as the avoided $\mathrm{CO}_{2}$ emissions. The contribution of renewable energysources and the assessment of the contribution of a CHCP system were also studied. For that, dynamic codes were used to obtain all the thermal needs of a hotel located in Portugal.

The simulations with nominal conditions (base case) showed thatthe total energy consumed in the building is $4.84 \mathrm{GWh} /$ year. Where, under the conditions set for this model, it achieved a $\mathrm{EEI}_{\text {nominal }}$ of 48.1 kgep $\mathrm{m}^{2-} \cdot$ year $^{-1}$, indicating that the building features an energy rating of $\mathrm{B}^{-}\left[\mathrm{EEI}_{\text {nominal }}(48.10)<\mathrm{EEI}_{\text {reference }}\right.$ (49.02) kgep $\cdot \mathrm{m}^{2-} \cdot \mathrm{year}^{-1}$. Regarding the emission level of $\mathrm{CO}_{2}$, this building would emit 1,320.5 equivalent tons of $\mathrm{CO}_{2}$ per year. The consumption of HVAC (heating, cooling, ventilation and pumps), represents $35.7 \%$ of primary energy consumption, lighting $30.1 \%$, consumption on the equipment is $27.6 \%$ and $6.6 \%$ referred to sanitary hot water and swimming pool water.

At a passive level, a sensitivity analysis to the base case was also done. Regarding the changes in the opaque envelope, the best solution was ALT1 shows a decrease in the consumption, both for heating (4.27\%) and cooling (14.3\%) and a consequent reduction of ventilation and pumping systems. The avoided $\mathrm{CO}_{2}$ emissions are $6.4 \%$ and the payback time is 5.6 years. Regarding the glazing envelope and from the results of the analysis it is concluded that a glass with a solar factor of 0.40 is the best one, since this solution becomes attractive in terms of payback time in the range of 7.3-10.6 years as a function of the different types of frames that can be used.

At an active level it was analyzed the use of solar thermal panels for hot water heating. The lower 
payback time is around 8 years. For this situation, the EEI is $41.5 \mathrm{Kgep} \cdot \mathrm{m}^{2-} \cdot \mathrm{year}^{-1}$ and becomes lower than the reference value, $44.1 \mathrm{Kgep} \cdot \mathrm{m}^{2-} \cdot$ year $^{-1}$. Also two types of photovoltaic panels were analyzed: amorphous silicon and poly-crystalline silicon. It was concluded that the amorphous silicon panels are penalized because they require more than twice the solar capture area. So it was chosenthe polycrystalline silicon panels whit 92 modules. The power pick is 20 $\mathrm{KWp}$ andthe EEI is $42 \mathrm{Kgep} \cdot \mathrm{m}^{2-} \cdot \mathrm{year}^{-1}$. With this solution, it was concluded that they contribute to a reduction of thermal needs of $25.2 \%$ and avoided emissions of equivalent tons of $\mathrm{CO}_{2}$ of $30.4 \%$. Regarding the use of CHCP the best solution chosen was a four stroke internal combustion engine running with natural gas, and coupled to an absorption chiller.The contribution of this type of engine to fulfill the heating requirements of the building lies in the range of $44 \%$ to $94 \%$ and for cooling the range is $39 \%-61 \%$ (depending upon the working system profiles). It is also concluded that, the use of this engine and its operatinghours, there is the economic viability of this technology as well as the obligation to use it (payback time $<8$ years).

Therefore, after all the changes carried out, the building was rated to class $\mathrm{A}$.

\section{References}

[1] Çengel, Y., and Boles, M. 2002. Thermodynamics.
Lisbon: Mc Graw Hill.

[2] Afonso, C. 2012. Thermodynamics for Engineers. Porto, Portugal: FEUP.

[3] Commission of the European Communities. 1997. A Review of Cogeneration Equipment and Selected Installations in Europe. Brussels: Directorate-General XVII for Energy, OPET.

[4] Afonso, C., Moutinho, T. 2014. "Energetic, Economical Analysis and Avoided $\mathrm{CO}_{2}$ Emissions in a Cogeneration System Regarding the Legislation." International Journal of Mechanical Engineering and Automation 1 (2): 93-100.

[5] EU Member States and Cogeneration Organizations. 2003. The European Association for the Promotion of Cogeneration. Brussels: Cogen Europe VZW.

[6] Polimeros, G. 2010. Energy Cogeneration Handbook. South Norwalk, CT 06854. New York: Industrial Press Inc..

[7] Official Diary of the Portuguese Republic. 1999. Decree-Law $n^{\circ}$ 538/99. CHP. Lisbon: Official Journal of the Assembly of the Portuguese Republic.

[8] Official Diary of the Portuguese Republic. 2001. Decree-Law $n^{\circ}$ 313/2001. CHP. Lisbon: Official Journal of the Assembly of the Portuguese Republic.

[9] Official Diary of the Portuguese Republic. 2007. Decree-Law $n^{\circ}$ 225/2007, Photovoltaics Systems. Lisbon: Official Journal of the Assembly of the Portuguese Republic.

[10] Official Diary of the Portuguese Republic. 2006. Decree-Law $n^{\circ}$ 79/2006, Regulation of Energy Systems for HCVAC of Buildings. Lisbon: Official Journal of the Assembly of the Portuguese Republic.

[11] Official Diary of the Portuguese Republic. Decree-Law $n^{\circ}$ 80/2006. Regulation Characteristics of the Thermal Performance of Buildings. Lisbon: Official Journal of the Assembly of the Portuguese Republic. 